NGTT Deel 54, Nommers 3 \& 4, September en Desember 2013

Verster, Pieter

Universiteit van die Vrystaat

\title{
Toekomsverwagting en hoop by inwoners in die informele nedersettings rondom Bloemfontein ${ }^{1}$
}

\section{ABSTRACT \\ Expectations of the future and hope of residents of informal settle- ments near Bloemfontein}

Is there any prospect of hope for the inhabitants of informal settlements? This question is asked concerning the inhabitants of informal settlements around Bloemfontein. An introductory section on the theological implications and Biblical aspects of hope is followed by the results of qualitative empirical research. Respondents replied in five ways. Some regarded the situation as without any hope (a) while others saw some hope if the government could become involved (b). Some saw the only hope in God changing the situation (c) while others believed that the church should be responsible for change (d) and, finally, some regarded it as the task of citizens of the country and the inhabitants of the informal settlements to take responsibility for change themselves (e). A theological perspective emphasizes individual hope in Christ as well as the renewal of society. The church has a definite task in achieving this.

\section{INLEIDING}

Daar is sterk aanduidings dat die positiewe toekomsverwagting en hoop wat deur die nuwe politieke bestel in Suid-Afrika meegebring is, nie gerealiseer het nie. Verwagtings is geskep wat nie nagekom is nie. Sekere positiewe ontwikkelings word oorskadu deur toenemende onrus. Is daar enige hoop vir inwoners van informele nedersettings rondom Bloemfontein? Is daar'n verwagting dat daar 'n nuwe toekoms geskep en 'n nuwe beginsel neergelê kan word van waaruit hierdie mense, wat dikwels onder haglike omstandighede lewe, 'n positiewe pad kan betree? Hierdie vrae beteken dat indringend gekyk moet word na die toekomsverwagting van mense onder bedreigende omstandighede.

\section{Metodologie en navorsingsontwerp}

Die betekenis van ' $n$ verwagting van hoop moet ontleed word. Om daarin te slaag, moet teologiese beginsels vanuit eksegetiese en hermeneutiese oorwegings neergelê word. 'n Deeglike literatuurstudie is dus nodig. Daarbenewens moet ondersoek ingestel word na verwagtinge van hoop in informele gemeenskappe in Mangaung, oos van Bloemfontein. ' $n$ Kwalitatiewe ondersoek is in hierdie verband die beste moontlikheid. Ongeveer 100 persone is in die verband genader. Informele gebiede is besoek en met die sneeubal metode is persone

1 Hierdie artikel is gebaseer op navorsing wat deur die NNR van Suid-Afrika ondersteun is. Alle standpunte, gevolgtrekkings en voorstelle wat gemaak word, is die standpunt van die outeur en die NNR aanvaar geen verantwoordelikheid daarvoor nie. Die navorsing is ook ondersteun deur die UV-kluster: "New frontiers in poverty reduction and sustainable development." 
NGTT: Oopbron - http://ngtt.journals.ac.za

genader. Om te verseker dat die onderhoude verteenwoordingend is, is daar telkens na nuwe gebiede gegaan.

Ten eerste moet daar ten opsigte van die aard van die omgewing waarin mense in die informele nedersettings rondom Bloemfontein in Mangaung woon, kennis geneem word van haglike omstandighede. Ten spyte van pogings deur die Mangaung Metropolitaanse Munisipaliteit, wat in baie opsigte pogings aangewend het om die nodige strukture te verskaf, bly dit nog in baie opsigte gebrekkig. Infrastruktuur soos paaie, sanitasie, hospitale, skole en klinieke is in 'n groot mate afwesig. Die ongestruktureerde invloei van mense word vererger deur persone wat die situasie uitbuit en die ontwikkeling van gebiede bemoeilik. Sommige inwoners kom van plase of dorpe in die Vrystaat maar daar is ook invloei vanuit Lesotho en ander Afrikalande. Spanning kom dan voor tussen die groepe, alhoewel xenofobiese aanvalle nie onlangs voorgekom het nie. Dikwels word sanitasie deur persone self by wyse van buite-toilette aangebring. Watervoorsiening is dikwels onvoldoende en soms ontoeganklik. Die huisvesting is baie karig en bestaan dikwels slegs uit enkele sinkplate wat gebruik word om huise op te rig. Die situasie word in baie opsigte vererger deur die feit dat baie van hierdie inwoners oor geen inkomste beskik nie, terwyl slegs enkeles regeringspensioen ontvang. Die gevolg is dat die omstandighede in baie opsigte indringend aandag moet geniet.

In navorsing in hierdie gebiede is dikwels op die omstandighede klem gelê en hoedat die kerk dan uit hierdie omstandighede hulp en leiding sou kon verskaf om vir die mense aktiewe hulp en leiding te bied.

In hierdie artikel val die klem op die wyse waarop 'n toekomsverwagting geskep kan word en wat hierdie toekomsverwagting inhou. Die navorsing sluit onderhoude oor die respondente se toekomsverwagting en wat die toekoms vir hulle in hierdie gebied inhou, in. ' $n$ Toekomsverwagting kan geskep word deur iemand se omstandighede te verander, maar ook deurdat mense nuut na hulle eie omstandighede kyk. Missiologies kan 'n besondere bydrae tot die skep van 'n toekomsverwagting gelewer word deur 'n Bybelse perspektief voor te hou.

\section{ToEkOMSVERWAGTing}

\section{1 'n Betekenisvolle toekomsverwagting}

Die verwagting van 'n nuwe toekoms is deel van die menslike bestaan. Sonder hoop is dit nie moontlik om te lewe nie. Hoe hierdie toekomsverwagting en hoop ingevul word, is van groot belang. Verskillende perspektiewe kom na vore. Vorster (2011:13) argumenteer dat die bring van hoop Suid-Afrika voor groot uitdagings stel. Rassisme, seksisme, xenofobie en ander vorme van spanning kom steeds voor. Alle vorme van die miskenning van menslikheid moet teengewerk word. Dit beteken dat die kerk sigself inderdaad profeties teen alle bedreigings van hoop in die samelewing moet uitspreek: "Christians should be the custodians of the value of life by speaking up against all violations of human dignity - especially where this value is trampled upon through racist hate speech, violence against foreigners and dehumanization of women."

Hoop moet dus geskep word deur die menslike bestaan te vernuwe. MacMillen (2011:241) beklemtoon juis dat geloof, hoop en liefde saamhang en dat die liefde die hoop op hierdie wêreld rig. Deur die liefde verkry die menslike bestaan nuwe betekenis en hoop word geskep. Ook Lennan (2011:253) beklemtoon dat hoop'n uitdaging is en dat die liefde van Christus ook 
NGTT Deel 54, Nommers 3\& 4, September en Desember 2013

beteken dat hoop die werking van genade in ons lewe uitdra. Dit is inderdaad betekenisvol. Hoop moet met die liefde van Christus ingevul word anders word dit dikwels leeg en sonder inhoud; 'n blote verwagting van iets nuuts. Die hoop wat saamhang met die volle vernuwing wat Christus bring, sluit die huidige en toekomstige lewe in. Moltmann et al. (2004:15) wil die eskatologiese hoop nuut interpreteer en is van mening dat Jesus wat as regter kom juis die Een is wat volledige versoening met God bring sodat universele heil deurbreek, maar daar sal van hulle verskil moet word dat die versoening en hoop universalisme veronderstel. Hoop as universele heil sal egter ook in die huidige bestaan reeds die gemeenskap tot ' $n$ lewe in hoop oproep. Wanneer die beslissing in Christus wat die hoop bepaal, nie ook as skeidende geregtigheid beskou word nie, verkry die hoop 'n verkeerde inhoud. Die begrip "teologie van hoop" word ook anders ingevul en Mashau (2008:31) wys op die betekenis wat' $n$ "teologie van hoop" kan inhou. Eerstens moet dit gevestig wees op die persoon en werk van Christus, omdat Hy Immanuel (God met ons) is wat Hom verneder het om in die menslike bestaan en leed te deel. Tweedens moet dit op die opstandingshoop van Jesus Christus gevestig wees. Die hoop op 'n beter toekoms is daarop gevestig. Derdens het die teologie van hoop betekenis vir die hier en nou. Die strydende kerk is op weg in hierdie wêreld, maar wil ook die nuwe heil bring met die verwagting op die toekoms waar alle verlossing sigbaar sal wees. Vierdens word die kerk opgeroep om by die wêreld betrokke te raak. Die stryd teen die boosheid en lyding in die wêreld moet aangeknoop word. Esterman (2003:112) wil juis die nood en ellende en angste van mense in die onontwikkelde wêreld met erns bejeën om sinvol oor hoop te praat (kyk ook Bockmuehl (2012:15). Holton (2010:81) sluit hierby aan deur aan te dui dat betrokkenheid in die ontvouing van God se beloftes van hoop in die wêreld van groot belang is. Die historiese hoop in Christus is egter essensieel (vgl. Ware (2009:137)).

Terwyl dit inderdaad waar is dat die teologie hoop moet beklemtoon, moet gewaak word teen 'n teologie waarin die betekenis van die dood van Christus aan die kruis misgekyk word. Die dood aan die kruis skep hoop maar veroordeel ook ongeloof en sonde. Die eskatologiese hoop wat weer deur die opstanding bevestig word is van beslissende betekenis. Hierdie hoop is egter die hoop in Christus. Dit moet aan die heil in Christus alleen verbind word.

Hoe kan hierdie hoop Bybels begrond word?

\subsection{Bybelse begronding}

Die eskatologiese verwagting in die Bybel is ononderhandelbaar maar het ook betekenis vir die hier en die nou. Die toekoms is steeds 'n ingevulde toekoms wat betekenisvol deur God bepaal word. Die eskatologiese heil is egter reeds in God se ingrepe in die werklikheid sigbaar.

\subsubsection{Die toekoms in die Ou Testament}

Watter uitgangspunte moet neergelê word vir 'n nuwe toekomsverwagting en hoe moet hierdie toekomsverwagting bereik word? Indien 'n mens vanuit die Ou-Testamentiese perspektief vra wat die toekomsverwagting van mense moet wees en hoedat ' $n$ verdere toekomsverwagting ontwikkel kan word, moet klem gelê word op die gedagte dat God in sy ingrepe in mense se lewensomstandighede die Een is wat elke nuwe toekoms skep. Nie alleen is Hy die God van die geskiedenis nie, maar Hy is ook die God van die toekoms. Hierdie God van die geskiedenis en die God van die toekoms word op velerlei wyses in die Ou Testament beskryf. God skep die nuwe toekomsverwagtinge.

Hoop en verwagtinge van die toekoms in die Ou Testament hang ten nouste met die verbond 
NGTT: Oopbron - http://ngtt.journals.ac.za

en met die belofte van God saam. Aan die een kant is die verbond die grondslag waarop hoop en verwagting vir die toekoms gebou kan word. Die grondslag vir die verbond vind ons wanneer God vir Abraham sê: "Ek sal vir jou 'n God wees, en jy moet my kind of my volk wees" (Gen.12). Uit hierdie verhouding tussen God en Abraham spruit die belofte dat die nasies ook geseënd sal wees, want "[i]n hom sal al die geslagte van die wêreld geseën wees" (Gen 12 3). (vgl. Wenham 2002a:282), Sailhamer (1990:138) verduidelik dat die verbond juis op twee beloftes van God berus, naamlik dat God'n oorvloedige nageslag sal gee, en ewige toewyding en seën. Hierdie verbondsverhouding beklemtoon ook'n nuwe bevestiging van die beloftes van God. Die beloftes van God skep hoop en verwagting dat die toekoms in God se hande is en dat God die toekoms in vervulling sal laat gaan. Hierdie beloftes van God verseker God se volk, diegene wat aan God behoort, van 'n seënryke toekoms. Dit vind sy hoogtepunt in die Josef-geskiedenis wanneer God sy beloftes aan die volk vervul toe Hy gesorg het dat hulle deur Josef in Egipte bewaar is (vgl. Wenham (2002b:493). en Sailhamer (1990:266)).

Verder vind die beloftes vervulling in Moses se geskiedenis wanneer Moses deur God geroep word en God in Moses beloftes vervul wat Hy aan die volk gedoen het (Kaiser 1990:486). Die hoogtepunt van daardie vervulling vind eers plaas wanneer Josua die land inneem, maar dit beteken dat God ook op 'n besondere wyse met die volk was en dat Hy hulle ook van 'n toekoms verseker.

Hierdie toekomsverwagting wat vervul word wanneer die beloftes in vervulling gaan, hang saam met die verbond en die vervulling van die verbondsbeloftes wanneer die toekoms ' $n$ werklikheid word.

Dit is veral Wright (2008:77-78) wat die besondere betekenis van die heil wat deur God in die uittog beklemtoon word verhelderend bespreek. Die God van die Bybel is die wonderbare Koning. Die heil van God is dus nie slegs geestelik en spiritueel nie, maar in die geskiedenis word dit konkreet en radikaal. Alle terreine van die lewe word geraak. God vernuwe die gemeenskap totaal op geestelike, ekonomiese, sosiale en politieke gebied. Hierdie heil het betekenis vir die hele gemeenskap.

Veral in Jesaja word dit baie sterk beklemtoon dat God die een is wat vir die volk wat in ballingskap, eintlik 'n volk sonder hoop met geen verwagting meer oor nie, verwagting en hoop kan skep. Hy doen dit deur vir hulle 'n nuwe toekoms te skep sodat hulle in die verwagting van wat God skep, vooruit kan beweeg in 'n rigting waarin hulle dan in 'n nuwe verhouding kan leef. Lessing (2011:134) maak'n saak daarvoor uit dat Israel as die kneg van die Here ook die Kneg van die Here nodig het: "Just as Adam needed a second Adam, so the servant needs a second servant. Isaiah, then, gives us two servants; one who is blind because of idolatry and in need of rescue, the other whose eyes and ears are wide open so he can be the rescuer. After the righteous servant's vicarious satisfaction for the servant's sin of idolatry, as well as for the sins of all (53:11), Israel is forensicaly deemed righteous by Yahweh (54:17c). Forgiven and cleansed, the nation is then able to take up their servant role anew." Nuwe verwagting word telkemale geskep wanneer God heil en verlossing moontlik maak en dit vir hulle skep. Kaminsky et al. (2006:162) beklemtoon God se volledige soewereiniteit en majesteit in Deutero-Jesaja. In Jesaja vind die hoop natuurlik' $n$ besondere betekenis wanneer God die spesifieke aard van die verlossing en die seën beklemtoon. In Jesaja word die heil vir die volk verseker, asook'n terugkeer uit die ballingskap waarvandaan hulle in heerlikheid sal terugkeer om die land in besit te neem. Verder verseker Jesaja hulle van die vervulling van die beloftes wanneer die hoop'n nuwe gestalte verkry en wanneer dit alles plaasvind, sal die 
NGTT Deel 54, Nommers 3 \& 4, September en Desember 2013

beloftes van God ten volle in vervulling gaan. Die liedere oor die kneg van die Here in Jesaja bevestig dit op 'n baie unieke en besonderse wyse. Hierdie heil wat God gee, hou hoop in vir die toekoms, onder andere in Jesaja 40:1-2 waar daar geskryf staan: “Die uitkoms is hier! Die uitkoms is hier! Dit, sê julle God, moet julle vir my volk sê. Bring vir Jerusalem die goeie tyding, sê vir hom sy swaarkry is verby, Hy het geboet vir sy sonde, hy het van die Here die volle straf ontvang vir al sy sondes." (vgl ook Grogan (1986:245-246)). Die Here bevestig hiermee dat daar hoop en 'n toekomsverwagting is en dat Hy die toekoms nuut kan skep.

In die profetiese literatuur kom dit telkemale voor dat daar te midde van die onheil en die oordeel van God telkemale ook heil en verlossing is. Die profetiese literatuur beklemtoon hierdie heil en verlossing sodat daar 'n toekomsverwagting is omdat God die een is wat die toekoms moontlik maak en 'n toekomsverwagting skep. So vind ons dit dan ook in 'n besondere sin in Daniël wanneer Daniël met sy skuldbelydenis voor God deur God verseker word van die toekoms wat God sal skep (Dan 9:20, vgl. Goldingay (2002:266).

Die Ou Testament beklemtoon dus op unieke wyse hoe God ingryp en heil skep sodat die hoop met volle inhoud gevul word. God skep die hoop soms uit totaal ellendige omstandighede sodat Hy geëer kan word. Die toekoms is volledig in sy hande.

\subsubsection{Toekomsverwagting in die Nuwe Testament}

Heil en verlossing en hoop in die Ou Testament is baie konkreet. In die Nuwe Testament (NT) is dit ewe-eens konkreet maar dit sluit 'n toekomsverwagting van heil in die ewigheid in. Dit bly nie uit dat die belofte van God in vervulling sal gaan in die heil wat God skep nie. Nie alleen in die verwagting op die ewigheid want God verseker die volk en die gelowige ook van die teenswoordige heil Die NT bied beloftes oor die heil wat volledig in die toekoms in vervulling sal gaan, 'n verlossing wat werklik en absoluut sal wees. Die belofte van vervulling in die toekoms word egter ook gebind aan die teenswoordige heil wat reeds in die teenswoordige tyd na vore kom. Daarom word verskillende aspekte van die toekomsverwagting en die teenswoordige heil. God se heil word in die teenswoordige tyd geskenk, maar die verwagting op die toekomstige heil bly nie uit nie. Daarom word die vervulling en die verwagting van die heil in die toekoms verder in die teenswoordige tyd bevestig. Juis dit gee hoop vir mense vir nou en vir die lewe hierna.

Dit vind ons veral in die Johannes-evangelie waar dit baie duidelik gemaak word dat die heil in die teenswoordige tyd beklemtoon word. God beklemtoon baie uitdruklik reeds in Johannes 6 dat die heil teenswoordig is. (Joh 6:47). Dit is 'n sterk bevestiging van die heil wat in die teenswoordige tyd reeds 'n werklikheid is. Beasley-Murray (2002:97-98) beklemtoon dit juis: "All this suggests that the feeding miracle is understood as a celebration of the feast of the kingdom of God in the present, anticipating its continual celebration in the Church's worship and its ultimate fulfillment in the last day." Tenney (1981:77) sluit hierby aan "Again Jesus says, 'I am the bread of life' (cf. v. 35). Before, he linked this statement with the supplying of man's basic needs; hunger and thirst would be permanently alleviated. This time Jesus links the statement to life itself. When the Jews ate the heavenly bread ("manna") in the wilderness, their physical needs were met. However, they still died (v.49). But Jesus said that he is the bread that comes down from heaven, which a man may eat and not die' (v.50)."

Dit word verder bevestig wanneer Jesus hierdie heil en verlossing aan sy persoon koppel en verseker dat Hy en die Vader een is en dat Hy in die eenheid met die Vader hierdie verlossing en heil kan gee wat tog vir die persoon in die tyd self betekenis het. Die versekering van die 
NGTT: Oopbron - http://ngtt.journals.ac.za

heil in die tyd self word in Romeine ook verder beklemtoon wanneer Paulus oor die werking van die Heilige Gees skrywe, hoe die Gees en die skepping deur God bestuur word omdat God die Heilige Gees gee (vgl. Dunn (2002:493) Harrison (1976:93-94) skryf ook: "Before passing to the final ministry of the Spirit (vv. 26, 27) Paul lingers over the concept of future glory in relation to present suffering. His presentation may be seen as an expansion of what he had already written to the Corinthians (2 Cor 4:17). Weighed in the scales of true and lasting values, the sufferings endured in this life are light indeed, compared with the splendor of the life to come-a life undisturbed by anything hostile or hurtful. Scripture does not tell us much of what that glory will be, but it assures us that it will be."

Alhoewel die hoop en verwagting soms 'n uitgestelde hoop is, soos blyk uit Hebreërs 11 waar aangedui word hoe die gelowige mens deur die geloof aan God verbind is, hoe die heilsverwagting beklemtoon word, hoe die mens uitsien na die verlossing wat van God kom en die verlossing en sekerheid vir hom gee wat in vervulling gaan. Hierdie verlossing tree egter nie altyd hier en nou volledig in werking nie, maar hulle leef met verwagting dat die belofte dit in vervulling sal gaan. Hebreërs 11 verseker gelowiges van die heil wat vir hulle gegee is omdat hulle deur die geloof die toekomstige heil in die verte gesien het ( Lane 2002:394-395). Morris (1981:131-132) verduidelik ook: "The despised and ill-treated group of servants of God was of greater real worth than all the rest of humanity put together. Their description is rounded off with the reminder that they had no settled homes. They wandered in lonely places, and their shelters were "caves and holes in the ground" (i.e., underground caves). The heroes of the faith had no mansions; they cared for other things than their own comfort."

Dan natuurlik in Openbaring word die belofte van heil baie sterk beklemtoon. Dit is ' $n$ heil wat ons in Christus se teenwoordigheid verkry wanneer Hy ons verseker van sy teenwoordigheid tussen die gemeentes, die sewe gemeentes waar $\mathrm{Hy}$ as Here teenwoordig is. Hy verseker sy verlossing en heil vir hulle, maar Hy verseker hulle ook dat hierdie heil en verlossing wat Hy aan hulle belowe ook in die toekoms ten volle na vore sal kom. Dit word verseker in Openbaring 7 waar die 144000 mense met die naam van sy Vader op hulle voorkoppe staan. Aune (2002a:480) skryf: "It is clear that the 'innumerable multitude' ( $v$ 9), which suggests the fulfillment of the promise to Abraham, consists of the large number Christians who have died or suffered martyrdom during the period of eschatological tribulation, during the same period that the 144,000 have been divinely protected from defeat and death." Dit is die verlossing wat in Openbaring 19 belowe word wanneer daar vreugde in die hemel is en die bruilof van die Lam aanbreek en die stem van die troon van God gekom en gesê het: "Loof ons God as sy dienaar, die wat Hom vrees klein en groot en dan die lof wat aan God gebring word vir die groot bruilofsmaaltyd van die Lam verlossing van die heil wat kom" (vgl. Aune 2002b:1040 en Johnson 1981:571).

Die Nuwe Testament beklemtoon dat God in Jesus Christus die heil skep, nie alleen vir die toekoms nie, maar ook vir die teenswoordige tyd. Hierdie heil omvat die mens se volle bestaan en bring hoop onder die mees ongunstige omstandighede. Dit word radikaal aan die kruis en opstanding van Jesus Christus verbind en word deur Hom bemiddel. Die heil wat Hy gee word die inhoud van die ware hoop..

\section{GemeEnSKappe SE VerWAgting}

Gedurende kwalitatiewe onderhoude wat tussen 2009 en 2013 met individue in informele behuisingsgebiede in Mangaung gevoer is, het dit duidelik geword dat daar by sommige 
NGTT Deel 54, Nommers $3 \& 4$, September en Desember 2013

respondente nie meer ' $n$ toekomsverwagting en hoop is nie. Onderhoude is in Sesotho of isiXhosa op band opgeneem en deur ds. T. Maile getranskribeer en vertaal. Toestemming vir onderhoude is telkemale verleen. Verskeie onderhoude wat op die sneeubal- en ander ongestruktureerde metodes gedoen is, maar telkens in ander informele gebiede, om die ondersoek so ruim as moontlik te maak. is in die tydperk met kerkleiers, lidmate en die algemene publiek (mense op straat) gevoer. Hierdie onderhoude is op kwalitatiewe navorsingswyse gevoer. Die struktuur wat gevolg is, was om vanuit vier ongestruktureerde platforms vrae te genereer om te bepaal hoe die beginsels van die evangelie in die informele gemeenskap gevestig kan word. Vanuit [A], die vraag na die lewensomstandighede van die gemeenskap, word beweeg na [B], die vrae aangaande die kerk se optrede in die gemeenskap om armoede en ander bedreigings teen te gaan, na [C], die vrae rondom die verwagte taak van die kerk in die gemeenskap om juis teen die bedreigings op te tree, na [D], ' $n$ vraag (vrae) of daar 'n toekomsverwagting en hoop is en hoe dit bereik moet word. Die laaste vraag [D] is vir hierdie artikel van belang.

Vanuit die onderhoude was daar die volgende vyf hoofreaksies:

1. Daar is geen hoop op 'n beter toekoms nie, hoofsaaklik as gevolg van die sosio-politieke omstandighede. Hierdie reaksie kom algemeen voor onder sowel die algemene publiek as by kerkgangers voor sodat dit nie as die oortuiging van slegs die nie-kerklike publiek beskou kan word nie. Voorbeelde van response is die volgende:

- $\quad$ Ek sien nie 'n toekoms nie.

- $\quad$ Nee, daar is nie'n toekoms nie, want'n mens kry net vir een dag hulp. Wat van die ander dae?

- $\quad$ Ek dink nie so nie, ons toekoms is gedoem.

- $\quad$ Nee, daar is nie 'n toekoms nie, want ons het nie'n raadslid nie en ons ken nie ons premier nie.

- $\quad$ Ek is nie positief oor die land se toekoms nie.

- Daar is geen toekoms nie.

2. Daar is hoop indien die regering of staatsinstellings ingryp. Dit kom voor by die algemene publiek en by kerkgangers wat daarop dui dat dit algemeen is Voorbeelde hiervan is soos volg:

- $\quad$ As die regering kan help om saam te baklei, sal alles regkom

- $\quad$ Slegs met opvoeding, seminare, werkswinkels om vaardighede te kry om armoede te verlig. Almal het geld nodig, dus moet hulle weet hoe om geld te maak.

- As die regering die kerke kan begin erken.

- $\quad$ As die regering projekte van stapel kan stuur, veral in landbou.

- $\quad$ As die regering kerke van raad kan bedien, nie met geld nie as gevolg van die korrupsie.

- $\quad$ Ek dink eenheid sal beter wees en as die regering die kerke kan help. Ons het werk nodig sodat ons vir ons gesinne kan voorsien. As die regering ons van werk of tenders kan voorsien. 
NGTT: Oopbron - http://ngtt.journals.ac.za

- Hulle behoort instellings soos universiteite te vra wat in verskillende departement hieraan werk om mense op te lei sodat hulle vaardighede kan hê om ons land te help om armoede te verlig. Ons kerklidmate het seminare, werkswinkels nodig om hulle toe te rus om hulle vaardighede vir die kerk te ontwikkel, veral by jong mense. Hulle kan navorsing oor hierdie epidemie doen.

- $\quad$ 'n Mens weet dit kan verander, slegs as die kerk en staat kan saamwerk, soos onder apartheid. Ons lees in die geskiedenis dat die kerk die staat se eerste prioriteit was.

- Ja, as die ryk mense kinders uit arm gesinne kan neem en hulle opvoed sodat daar in die toekoms minder armoede is.

- $\quad$ Ek is baie positief oor die toekoms in hierdie area. As die regering net skole, kerke en ander belangrike fasiliteite kan bou wat mense die kans kan gee om hulle lewens te verander.

3. Daar is hoop op 'n beter toekoms maar slegs by God. Hy alleen kan hoop skep. Dit kom voor by kerkgangers wat die verwagting van hoop aan God bind. Nie-kerklike respondente sien dit anders. Die volgende is voorbeelde van hierdie siening:

- Ja, dinge kan inderdaad verander, maar net as ons saamwerk en God vra om in alles die leiding te neem.

- $\quad$ Ek glo ons kan die toekoms verander, maar slegs as ons op God vertrou en Hom altyd nooi om die bron te wees van alles wat ons omring.

- As God net hierdie area kan seën.

4. Die kerk kan deur betrokkenheid by die gemeenskap hoop skep, maar dan moet die klimaat vir die kerk geskep word om met byvoorbeeld aanvaarbare standplase die werk te verrig. Kerkleiers huldig hierdie standpunt en wel op die volgende wyse:

- Ja, slegs as die kerk en die lidmate liefde en barmhartigheid kan beoefen en saam projekte kan aanpak,

- $\quad$ Ons wil hê die regering moet vir ons 'n standplaas gee waar ons 'n projek kan loods om te boer en groente te plant. Ons kan dan die groente verkoop en met die geld wat ons kry, kan ons die behoeftiges help.

- $\quad$ As die jonges maar net wil kerk toe kom

- Ja, daar is altyd 'n toekoms. Die kerk preek altyd die evangelie vir ons, maar ons wil nie na die boodskap luister nie.

- $\quad$ Ek glo ons as Christene moet ons houding verander, dan sal God ophou om mense te straf.

- Mense wat nie werk nie, het dalk iets soos masjinerie nodig sodat hulle klere kan maak en dit in die kerk verkoop. Omdat daar egter nie 'n kerk is nie, kan ons nie ons masjinerie kerk toe bring sodat mense kan werk nie. Ons moet eers 'n kerk kry sodat ons kan weet alles is veilig.

5. Indien verantwoordelikheid aanvaar word. Die volgende is voorbeelde:

- Ja, positief, dinge sal in die toekoms verander, maar net as ons kan opstaan en met 
NGTT Deel 54, Nommers 3 \& 4, September en Desember 2013

ons hande werk, met ons breine dink, kan ons saam met die kerk die situasie verander. Hoewel ons dit nie gaan klaarmaak nie, kan ons die situasie verander.

- Ja, want die meeste van ons is besig om die een of ander plannetjie te maak om ons eie mense hier te help.

- Ja, daar is ' $n$ toekoms. Dit is in ons hande.

- $\quad$ As alle kinders kan sien dat opvoeding die sleutel tot 'n beter toekoms is.

\section{Gevolgtrekking}

Alhoewel daar nie gekwantifiseer word in kwalitatiewe navorsing nie, het 'n beduidende aantal respondente (meer as 10\%) aangetoon aan dat hulle geen hoop op die toekoms het nie. Dit blyk dat hulle wanhoop uit die sosio-polities-ekonomiese toestand in die informele gemeenskappe spruit. Hierdie groep verwag ook nie dat die kerk hoop kan bring nie. Die kerk sal juis hiervan moet kennis neem en sigself afvra hoe om in die gemeenskap vir alle mense bakens van hoop te kan word.

'n Besondere groot aantal (meer as 20\%) is van mening dat die owerheid en instellings die situasie aansienlik kan verbeter, dikwels in samewerking met die kerk. 'n Profetiese stem vanuit die kerk sou die owerheid kon inspireer om meer betrokke te raak by die gemeenskap. Daar sal egter steeds 'n afstand tussen kerk en owerheid behou moet word.

Die transendente is in die gemeenskap steeds van besondere betekenis en dit is nie vreemd dat die verwagting leef dat God alleen deur sy ingrepe hoop kan skep nie. Die kerk sou inderdaad radikaal kon beklemtoon dat God die enigste een is wat werklik hoop kan skep.

Die kerk is steeds vir baie mense die gemeenskap wat inderdaad die nuwe toekoms kan skep. Onder haglike omstandighede bring die kerk nuwe verwagtinge by mense. Hierdie aspek sal ontwikkel en uitgebou moet word.

Dit is egter ook belangrik dat daar besef word dat gemeenskappe self ook verantwoordelikheid moet aanvaar. Die respondente wat hierdie aspek uitlig verleen inderdaad besondere betekenis aan die roeping om self ook by situasies betrokke te raak om nuwe hoop te skep.

\section{VOORSTELLE VIR DIE SKEP VAN 'N TOEKOMSVERWAGTING}

Hoe het die verlossing wat bevestig word in die heil wat vas lê in die toekoms vir'n persoon in 'n plakkerskamp betekenis? Op watter manier kan hierdie beloftes van God ook daar reeds in vervulling gaan? Is daar aspekte van die heil wat teenswoordig midde in daardie omstandighede ervaar en beleef kan word?

Dit is duidelik dat daar 'n brug geslaan sal moet word tussen die belofte van God binne die verbond en die bestaan van mense in die algemeen en hoe mense in die algemeen op hierdie hoop en verwagting kan staatmaak.

In die eerste plek is daar die persoonlike verhouding tot God waarin die hoop sekerheid verkry en 'n mens uit die krag van hoop kan lewe. Dit is alleen moontlik wanneer die persoon in 'n noue verhouding met God gebring word en ook in die teenwoordigheid van God kom. Die vraag wat egter onmiddellik gevra moet word, is of hierdie verwagting van'n persoonlike 
NGTT: Oopbron - http://ngtt.journals.ac.za

verbondsverhouding wat op 'n toekomsverwagting kan uitloop nie 'n tipiese voorbeeld van Christelike vermyding van die werklikheid is nie? 'n Sterk evangelisasie aksie sal dus in die gebiede geloods moet word, maar dit sal gevul moet word met wêreldbeskoulike inhoud sodat daar nie sprake van dualisme is waar die huidige lewe geskei word van die spirituele lewe nie. Kerkies in die informele gebiede moet mense aktief uitnooi na eredienste en aanbiddingsgeleenthede om 'n gemeenskap van hoop te vorm.

Dit is inderdaad van groot belang, want indien 'n persoonlike verhouding met God daartoe lei dat 'n mens jou aan die werklikheid onttrek en jy jou in 'n tipe geestelike kloosterbestaan bevind, word die betekenis en die ware aard van die hoop en toekomsverwagting van die Bybel meteens misgekyk. Die hoop en die toekomsverwagting van die Bybel hang saam met die sekerheid dat die heil en verlossing in Christus gevind kan word en dat hierdie heil en verlossing dit moontlik maak om dan met God te lewe en die toekoms tegemoet te gaan. Hierdie nuwe toekomsverwagting maak dit moontlik dat 'n mens ook verantwoordelikheid kan aanvaar.

Dit bring ons by die tweede aspek, die mens se verantwoordelike lewe voor God. Die mens word geroep tot 'n verantwoordelike lewe voor God. God gee die mens die taak en die verantwoordelikheid om in die werklikheid te leef.

Verantwoordelikheid hang ook met gemeenskapsverantwoordelikheid saam. Die individuele persoon in die informele behuisingsgebiede kan dikwels nie verantwoordelikheid aanvaar vir infrastruktuur en ander sake wat negatief op die gemeenskap inwerk nie. Hulle moet hulp ontvang van mense wat hulle ondersteun en die gemeenskap moet saam hierdie verantwoordelikheid aanvaar. Kerke sal selfs tydelike strukture moet oprig om mense te bedien. Daar sal gepoog moet word om die strukture wettig op te rig. Vanuit hierdie strukture moet die gemeenskap bedien word met crèches, opleiding en selfs primêre mediese dienste. As voorbeeld van gemeenskapdiens sou kerke aksies kon loods soos skoonmaakaksies, padopvullings en hulp met watervoorsiening.

Munisipaliteite is onder druk om vir mense behuising en dienste te verskaf. Dit is in baie opsigte nie moontlik om almal tegemoet te kom en hierdie dienste vir almal te verskaf nie. Die gemeenskap moet ook self verantwoordelikheid aanvaar om daarby betrokke te raak. Die kerk kan hierin 'n besondere rol vervul, nie alleen deur die spreekbuis van die armes te wees nie maar ook deur die owerhede by te staan in die ontwikkeling van die gebiede.

Die derde aspek is die skep van 'n nuwe toekoms en 'n nuwe verwagting deurdat daar van buite hulp kom. Dit kan geskied deur NRO's of deur die kerk self wat in die gemeenskap God se beloftes in vervulling laat gaan deur ook vir die gemeenskap hoop te skep en hulle deur daardie hoop op 'n nuwe pad te plaas. Dit sou kon beteken dat mense ander mense op die mees basiese vlak versorg sodat hulle nie in wanhoop verkeer en geen hulp en geen bystand kan verkry nie. Kerke moet aksies saam met ander rolspelers bevorder om die omstandighede prakties te verbeter. As uitvloeisel van hierdie navorsing word ' $n$ byeenkoms op 8 September 2013 gehou waar predikante en ander rolspelers geïnspireer word om (a) mense sonder hoop in die informele gebiede te identifiseer, (b) aksies te loods om die armes van basiese versorging te voorsien, (c) genootskappe te sluit om saam op te tree teen sake wat hoop vernietig, soos misdaad en (d) gemeenskaplike verantwoordelikhede te bevorder.

Werkskepping sou inderdaad noodsaaklik wees indien groot gebiede onder werkloosheid gebuk gaan. Hierdie werkskepping moet uiteindelik daartoe lei dat mense ook gehelp word 
NGTT Deel 54, Nommers $3 \& 4$, September en Desember 2013

met dit wat hulle wil doen sodat hulle dan inderdaad die gemeenskap verder kan opbou.

In die vierde plek sal 'n toekomsverwagting daartoe moet lei dat mense as burgers van die land hulle verantwoordelikheid nie alleen teenoor mekaar nie maar teenoor die land as sodanig nakom deur positiewe dinge tot opbou van die gemeenskap te doen.

Die uitdagings in die informele gebiede is ontsaglik groot. Daar is geweldige krisisse en hierdie krisisse kan alleen beantwoord word indien daar 'n diep Bybelse beginsel neergelê word dat God die een is wat die hoop skep. Terselfdertyd sal die gemeenskap ook verantwoordelikheid moet aanvaar en sal owerhede en ander belanghebbendes steeds direk betrokke moet wees by mense en ook insien hoedat hulle die mense te hulp kan kom en hulle op 'n nuwe pad kan plaas. Dit beteken dat gemeenskappe meer as ooit vantevore geïnspireer moet word om kennis te neem van die Bybelse uitgangspunte en van die wyse waarop die Bybel tog vir mense onder hulle omstandighede en die omstandighede waarin hulle lewe, riglyne kan verskaf en vir hulle op'n nuwe pad kan plaas.

Vanuit die wonder van God se nuwe skepping, wat Hy in Jesus Christus moontlik maak, is dit moontlik om ook in die hier en die nou reeds vir sake van belang verantwoordelikheid te neem. 'n Makro-struktuur wat dit moontlik maak, is van groot belang. 'n Makrostruktuur waarin mense inderdaad ruimte kan vind, moet beklemtoon word. Mense moet inderdaad die ruimte gebied word om vanuit hierdie makrostruktuur steeds voort te gaan om hulleself te ontwikkel.

\section{SLOT}

Die verwagting van 'n nuwe toekoms is alleen moontlik wanneer daar vanuit die diepte van die evangeliese beginsel dat Christus die Verlosser is, gedink kan word oor die werklikheid waarbinne ons leef en wanneer daar vanuit hierdie verlossing'n toekoms geskep kan word.

\section{BibliografiE}

Aune, D.E. 2002a. Revelation 6-16. Word Biblical Commentary Vol. 52B. Word Biblical Commentary. Dallas: Word, Incorporated.

Aune, D.E. 2002b. Revelation 17-22. Word Biblical Commentary Vol. 52C. Word Biblical Commentary. Dallas: Word, Incorporated.

Beasley-Murray, G.R. 2002. John. Word Biblical Commentary Vol. 36. Word Biblical Commentary. Dallas: Word, Incorporated.

Bockmuehl, M.A. 2012. Hope and optimism in straitened times. Pro Ecclesia 21(1): 7-24.

Boorer, S. 1998. Job's hope: a reading of the Book of Job from the perspective of hope. Colloquium 30(2): 101-122.

Dunn, J.D.G. 2002. Romans 1-8. Word Biblical Commentary Vol. 38A. Word Biblical Commentary. Dallas: Word, Incorporated.

Durham, J.I. 2002. Exodus. Word Biblical Commentary Vol. 3. Word Biblical Commentary. Dallas: Word, Incorporated.

Estermann, J. 2003. Theology of hope or hope for theology? Exchange 32(2): 109-122.

Goldingay, J.E. 2002. Daniel. Word Biblical Commentary Vol. 30. Word Biblical Commentary. Dallas: Word, Incorporated.

Grogan, G.W. 1986. Isaiah. In F. E. Gaebelein (Ed.), The Expositor's Bible Commentary, Volume 6: Isaiah, Jeremiah, Lamentations, Ezekiel (F. E. Gaebelein, Ed.). Grand Rapids, MI: Zondervan Publishing House.

Harrison, E.F. 1976. Romans. In F. E. Gaebelein (Ed.), The Expositor's Bible Commentary, Volume 10: Ro- 
NGTT: Oopbron - http://ngtt.journals.ac.za

mans Through Galatians (F. E. Gaebelein, Ed.). Grand Rapids, MI: Zondervan Publishing House.

Hessel-Robinson, T. 2010. Nurturing hope in the face of ecotastrophe: Advent, eschatology, and the future of creation. Liturgical Ministry 19(1): 9-20.

Holton, M. 2010. "Our hope comes from God": faith narratives and resilience in Southern Sudan. Journal Of Pastoral Theology 20(1): 67-84.

Johnson, A.F. 1981. Revelation. In F. E. Gaebelein (Ed.), The Expositor's Bible Commentary, Volume 12: Hebrews Through Revelation (F. E. Gaebelein, Ed.). Grand Rapids, MI: Zondervan Publishing House.

Kaiser, W.C., Jr. 1990. Exodus. In F. E. Gaebelein (Ed.), The Expositor's Bible Commentary, Volume 2: Genesis, Exodus, Leviticus, Numbers (F. E. Gaebelein, Ed.). Grand Rapids, MI: Zondervan Publishing House.

Kaminsky, J.S.; Stewart, A. 2006. God of all the world: universalism and developing monotheism in Isaiah 40-66. Harvard Theological Review 99 (2):139-163.

Lane, W.L. 2002. Hebrews 9-13. Word Biblical Commentary Vol. 47B. Word Biblical Commentary. Dallas: Word, Incorporated.

Lessing, R. 2011. Isaiah's servants in chapters 40-55: clearing up the confusion

Concordia Journal 37 (2): 130-134.

Lennan, R. 2011. The church as a sacrament of hope. Theological Studies 72(2): 247-274.

Lewis, J. 2011. Salvation, pseudo-modernism, suffering and hope: a study of I Kings 17. Evangelical Review Of Theology 35(4): 360-364.

MacMillen, S. 2011. A sociologist appeals to theological hope in postmodern apocalypses. Cross Currents 61(2): 232-244.

Mashau, T.D. 2008. Where and when it hurts most: the theology of hope and accompaniment in the context of HIV and Aids in marriage and family life. Exchange 37(1): 23-34.

Moltmann, J., Nausner, M., Collins Winn, C. T., \& Heltzel, P. 2004. The hope for the kingdom of God and signs of hope in the world: the relevance of Blumhardt's theology today. Pneuma 26(1): 4-16.

Morris, L. 1981. Hebrews. In F. E. Gaebelein (Ed.), The Expositor's Bible Commentary, Volume 12: Hebrews Through Revelation (F. E. Gaebelein, Ed.). Grand Rapids, MI: Zondervan Publishing House.

Sailhamer, J.H. 1990. Genesis. In F.E. Gaebelein (ed.), The Expositor's Bible Commentary, Volume 2: Genesis, Exodus, Leviticus, Numbers (F.E. Gaebelein, ed.). Grand Rapids, MI: Zondervan Publishing House.

Tenney, M.C. 1981. John. In F.E. Gaebelein (ed.), The Expositor's Bible Commentary, Volume 9: John and Acts (F.E. Gaebelein, ed.). Grand Rapids, Ml: Zondervan Publishing House.

Vorster, J.M. 2011. An ethics of hope for moral renewal in South Africa. Journal Of Theology For Southern Africa (140): 4-19.

Ware, J.P. 2009. Paul's hope and ours: recovering Paul's hope of the renewed creation. Concordia Journal 35(2): 129-139.

Wenham, G.J. 2002. Genesis 1-15. Word Biblical Commentary Vol. 1. Word Biblical Commentary. Dallas: Word, Incorporated.

Wenham, G.J. 2002. Genesis 16-50. Word Biblical Commentary Vol. 2. Word Biblical Commentary. Dallas: Word, Incorporated.

Wright, C.J.H. 2008. The mission of God: Unlocking the Bible's grand narrative. Nottingham: IVP. 